\title{
Effect of Cellulose Nanocrystals Content and pH on Swelling Behaviour of Gelatin Based Hydrogel
}

(Kesan Kandungan Selulosa Nanohablur dan pH terhadap Sifat

Pembengkakan Hidrogel yang Berasaskan Gelatin)

\author{
OOI SHOK Yin, IsHaK AHMAD* \& MOHD CAIRUl IQBAL MOHD AMIN
}

\begin{abstract}
In this research, a novel method was performed to obtain hydrogel with superior thermal stability by incorporation of cellulose nanocrystals $(\mathrm{CNC})$ into gelatin based hydrogel. Glutaraldehyde was used as cross-linker due to its high chemical reactivity towards $\mathrm{NH}_{2}$ group on gelatin. Different ratio of gelatin/CNC hydrogel was produced in order to study the effects of CNC towards the swelling behaviour and thermal stability of gelatin based hydrogel. The obtained hydrogel was subjected to Fourier transform infrared (FTIR) to verify that gelatin had been cross-linked, swelling test with different $p H$ for swelling behaviour and thermogravimetric analysis (TGA) for thermal stability. The presence of $C=N$ stretching group in the FTIR spectrum for gelatin/CNC hydrogel indicated that the cross-linking reaction between gelatin monomer had been successfully carried out. The hydrogel showed impressive pH sensitivity and maximum swelling was obtained at pH3. The TGA results clearly showed that the incorporation of CNC into gelatin was able to produce hydrogel with higher thermal stability compare to neat gelatin.
\end{abstract}

Keywords: Cellulose nanocrystals; cross-linking; gelatin; hydrogel; swelling behavior

\section{ABSTRAK}

Dalam kajian ini, kaedah baru telah digunakan untuk menghasilkan hidrogel yang mempunyai kestabilan terma yang lebih tinggi dengan penambahan selulosa nanohablur (CNC) ke dalam hidrogel yang berasaskan gelatin. Glutaraldehid telah dipilih sebagai agen taut silang bagi mentaut silangkan gelatin disebabkan ia mempunyai kereaktifan kimia yang tinggi terhadap kumpulan $\mathrm{NH}_{2}$ pada gelatin. Hidrogel gelatin/CNC dengan nisbah yang berbeza telah dihasilkan untuk mengkaji kesan penambahan CNC terhadap sifat pembengkakan dan kestabilan terma hidrogel. Hidrogel yang dihasilkan telah dicirikan dengan meng gunakan transformasi Fourier inframerah (FTIR) untuk mengesahkan terdapat tindak balas taut silang antara monomer gelatin. Ujian pembengkakan pula dijalankan untuk mengkaji sifat pembengkakan hidrogel pada pH yang berbeza manakala analisis termogravimetri (TGA) pula digunakan untuk mengkaji kestabilan terma hidrogel yang dihasilkan. Kewujudan puncak regangan kumpulan $C=N$ pada spektrum FTIR menunjukkan bahawa monomer gelatin telah berjaya ditaut silangkan. Hasil kajian menunjukkan bahawa hidrogel yang dihasilkan mempunyai sensitiviti yang baik terhadap pH dan hidrogel mencapai nisbah pembengkakan maksimum pada pH3. Analisis TGA pula menunjukkan penambahan CNC ke dalam hidrogel telah meningkatkan kestabilan terma hidrogel.

Kata kunci: Gelatin; hidrogel; selulosa nanohablur; sifat pembengkakan; taut silang

\section{INTRODUCTION}

Hydrogels are hydrophilic three dimensional polymer networks which may absorb up to thousands times of their dry weight in water or biological fluids due to the presence of hydrophilic groups such as $-\mathrm{OH},-\mathrm{CONH}-,-\mathrm{CONH}_{2}$, $-\mathrm{COOH}$ and $-\mathrm{SO}_{3} \mathrm{H}$ (Prestwich et al. 1998). They are able to retain large amount of water yet remain insoluble due to physical or chemical cross-links (Bell \& Peppas 1996). Stimuli-responsive hydrogels are hydrogels that undergo large volume changes in response to slight environmental changes. The environment sensitive hydrogels are also called 'smart' hydrogels. The physical stimuli include temperature (Jagadeeshbabu et al. 2011; Zhang et al. 2009), electric fields ( Li et al. 2004; Murdan 2003), light (Qiu \& Park 2012), pressure (Qiu \& Park 2012) and magnetic fields (Liu et al. 2006; Paulino et al. 2012), while the chemical stimuli include pH ( Frutos et al. 2010; Karlsson \& Gatenholm 1999) and ions (Rodrı'guez et al. 2003). A number of studies had focused to broaden the applications of these kind of hydrogel in various field (Lindblad et al. 2007; Wu et al. 2008), including controlled drug delivery (Zhang et al. 2013), tissue engineering (Hou et al. 2010), gene transfection (Gojgini et al. 2011) and sensors (Frisk et al. 2007).

Hydrogels can be produced from natural polymer (Shang et al. 2008) as well as synthetic polymer (Moriyama et al. 2013). Hydrogels based on natural polymer, such as gelatin, had been widely used as a raw material in hydrogel preparation due to their prominent characteristic such as high water absorption, low cost, good biocompatibility 
and biodegradability (Chen et al. 2011a; Wan et al. 2000). Gelatin is a type of protein derived from partial hydrolysis of native collagens that can be found in the animals' skins, tendons, cartilages and bones (Ward \& Courts 1977). Gelatin can forms physical thermo-reversible gels where they are in gels state at room temperature and melt at temperature above $37^{\circ} \mathrm{C}$ (Pezron et al. 1991; Ross-Murphy 1992). In order to stabilize these gels and improve its thermal and the mechanical properties, gelatin need to be cross-linked (Draye et al. 1998). The presence of large amount of amino acids' side chain groups in gelatin, make it readily undergoes chemical crosslinking (Spizzirri et al. 2009). Various chemical reagents including carbodiimide (Kuijpers et al. 1999), formaldehyde (Carvalho \& Grosso 2004), glutaraldehyde (Farris et al. 2009) and genipin (Bigi et al. 2002) or enzymes such as transglutaminase (Zhu et al. 2012) had been used to chemically cross-link gelatin chains in order to increase the gel's performance. So far, glutaraldehyde is most widely used in gelatin cross-linking because it's inexpensive, easily available and has high efficiency in stabilizing collagenous materials (Khor 1997).

The main disadvantage of gelatin is due to its poor mechanical properties (Lee \& Mooney 2001; Lee et al. 2004), which limit its possible applications as a biomaterial. In order to improve its mechanical and thermal stability, $\mathrm{CNC}$ have been incorporated into gelatin hydrogels. CNC consist of rod like cellulose crystals with widths of 5-70 $\mathrm{nm}$ and lengths between $100 \mathrm{~nm}$ and several micrometers. CNCs are obtained by acid hydrolysis where the amorphous regions of a purified cellulose were removed and the crystalline domains were kept intact (Klemm et al. 2011). Recently, CNCs has received a great deal of attention as the reinforcement of nano composites and polymeric hydrogel matrices because of their excellent properties, such as high mechanical strength, high aspect ratio (Eichhorn 2011), low density (about $1.57 \mathrm{~g} / \mathrm{cm}^{3}$ ), non-toxic, biocompatibility and biodegradability. Moreover, CNCs are produced from renewable natural sources which are abundant and readily available (Peng et al. 2011). Zhang et al. (2010) has prepared hydrogels using cyclodextrin and $\mathrm{CNC}$ and the results showed that the addition of $\mathrm{CNC}$ had successfully enhanced the gelation of hydrogel, which lead to improvement in mechanical properties and facilitates sustained release of drugs.

The aim of this study was to increase the thermal stability and to study the swelling behaviour of gelatin hydrogel by incorporation of CNC into gelatin hydrogel. The swelling test of hydrogel is carried out at different $\mathrm{pH}$ range from $\mathrm{pH} 3$ to 11 to investigate the optimum swelling behaviour.

\section{MATERIALS AND METHODS}

\section{MATERIALS}

Pharmaceutical grade gelatin was purchased from Halagel (M) Sdn.Bhd. Rice husk was acquired from Bernas
Malaysia Sdn. Bhd. Acetic acid, sodium chlorite, sodium hydroxide, sulphuric acid, glutaraldehyde and acetone were purchased from System ChemAR and Sigma-Aldrich.

\section{PREPARATION OF CNC FROM RICE HUSK FIBERS}

Three chemical treatments which involved in the preparation of $\mathrm{CNC}$ from rice husk were alkaline treatment, bleaching and acid hydrolysis. For alkaline treatment, 50 $\mathrm{g}$ of grinded rice husk were treated with 4 wt. $\% \mathrm{NaOH}$ at $90^{\circ} \mathrm{C}$ for $2 \mathrm{~h}$ under reflux condition for four times. After alkaline treatment, the fibers were subjected to bleaching process. Three solutions were involved in bleaching process, which were buffer solution of acetic acid, aqueous chlorite (1.7 wt. \%) and distilled water. The fibers were mixed with these three solutions at certain portions at $100^{\circ} \mathrm{C}$ for $4 \mathrm{~h}$ under reflux condition and were carried out for six times. Acid hydrolysis was performed using 65 wt. $\% \mathrm{H}_{2} \mathrm{SO}_{4} 5 \mathrm{~g}$ of cellulose and 65 wt. $\% \mathrm{H}_{2} \mathrm{SO}_{4}$ were placed into a beaker and stirred using magnetic bar at $45^{\circ} \mathrm{C}$. After $30 \mathrm{~min}$, the mixture was then placed into an ice bath to stop the reaction. The suspension was then washed by centrifugation at $4500 \mathrm{rpm}$ at $10^{\circ} \mathrm{C}$ for $10 \mathrm{~min}$. This washing process was repeated 10 times before it is placed into dialysis tube for dialysis against distilled water until $\mathrm{pH}$ was neutral. The resulting suspension was then kept refrigerated for further used.

\section{PREPARATION OF GELATIN /CNC HYDROGELS}

Adequate quantities of $\mathrm{CNC}$ were dispersed in $50 \mathrm{~mL}$ of water. The $\mathrm{CNC}$ suspension was then homogenized using a homogenizer to ensure the CNC suspended uniformly. Certain amount of gelatin was then added into $\mathrm{CNC}$ suspension. The mixture was then stirred at $55^{\circ} \mathrm{C}, 2$ wt. $\%$ of glutaraldehyde which act as cross-linking agent was then added dropwise once a homogeneous viscous mixture was obtained. The mixture was poured into a petri dish after 4 $\mathrm{h}$ and placed in oven at $45^{\circ} \mathrm{C}$ until the mixture was dried. Hydrogels in the form of thin films were removed from the petri dish and washed with distilled water to remove unreacted chemicals. Acetone in a Soxhlet apparatus was then used to extract aldehyde and water traces. The film was then dried in an oven at $45^{\circ} \mathrm{C}$. The gelatin/CNC composition was tabulated in Table 1.

\section{CHARACTERIZATION}

Dimensions of the $\mathrm{CNC}$ extracted from rice husk fiber were determined by transmission electron microscopy (TEM) (model Philips CM 12). A drop of a diluted CNC suspension was deposited on the surface of a clean copper grid covered with a thin carbon film. The $\mathrm{CNC}$ were negatively stained with 2 wt. \% solution of uranyl acetate for $10 \mathrm{~s}$ to enhance the contrast and then washed using $50 \mathrm{wt}$. \% of filtered alcohol. Before the TEM analysis was carried out, the sample was allowed to dry at room temperature.

The changes in the functional groups in $\mathrm{CNC}$ after various chemical treatment and gelatin/CNC hydrogel 
TABLE 1. Composition of Gelatin/CNC hydrogel

\begin{tabular}{ccc}
\hline Weight $\%$ of CNC & Weight of gelatin $(\mathrm{g})$ & Weight of CNC $(\mathrm{g})$ \\
\hline 0 & 5.00 & 0.00 \\
1 & 4.95 & 0.05 \\
2 & 4.90 & 0.10 \\
3 & 4.85 & 0.15 \\
4 & 4.80 & 0.20 \\
5 & 4.75 & 0.25 \\
\hline
\end{tabular}

was determined using FTIR spectroscopy (Perkin-Elmer, GX Model). The samples were grounded and mixed with potassium bromide, $\mathrm{KBr}$ in the ratio of $1: 1$. The mixture was then compressed into pellets and analyzed in transmittance mode within the range of $4000-400 \mathrm{~cm}^{-1}$.

5 buffers solution of $\mathrm{pH} 3,5,7,9$ and 11 were prepared. The swelling behaviour of neat gelatin and gelatin/CNC hydrogel were measured by immersing the dried hydrogel in buffer solutions at different $\mathrm{pH}$. The hydrogel samples were taken out from the buffer solution at predetermined time intervals, the excess buffer solution on the surface of hydrogel were then removed using filter paper before weighing them. The swelling percentage of the hydrogel can be calculated as:

$$
\text { Swelling }(\%)=\frac{\mathrm{W}_{\mathrm{t}}-\mathrm{W}_{0}}{\mathrm{~W}_{0}} \times 100 \% \text {, }
$$

where $\mathrm{W}_{\mathrm{t}}$ is the weight of swollen hydrogel and $\mathrm{W}_{0}$ is the initial weight of hydrogel.
Mettler Toledo thermogravimetric analyser (TGA/ SDTA $851^{\mathrm{e}}$ ) was used to determine the thermal stability of gelatin/CNC hydrogel. The materials were heated from 50 to $800^{\circ} \mathrm{C}$ at a heating rate of $10^{\circ} \mathrm{C} \mathrm{min}^{-1}$ under a nitrogen atmosphere with a gas flow of $10 \mathrm{~mL} \mathrm{~min}{ }^{-1}$.

\section{RESULTS AND DISCUSSION}

\section{MICROSCOPY}

Figure 1 shows the transmission electron micrographs of $\mathrm{CNC}$ extracted from the rice husk. Acid hydrolysis treatment was carried out in order to remove the amorphous part of cellulose and leaving the crystalline part intact. After acid hydrolysis, the size of fibres will reduced from micrometer to nanometer (Azizi Samir et al. 2005). From the TEM image, rods like shape of CNC can be clearly observed and they were characterized by their diameter (D), length (L) and aspect ratio (L/D). The dimensions of CNC were shown in Figure 1. CNC displayed a diameter of 5-10 nm with aspect ratio around $10-50$.

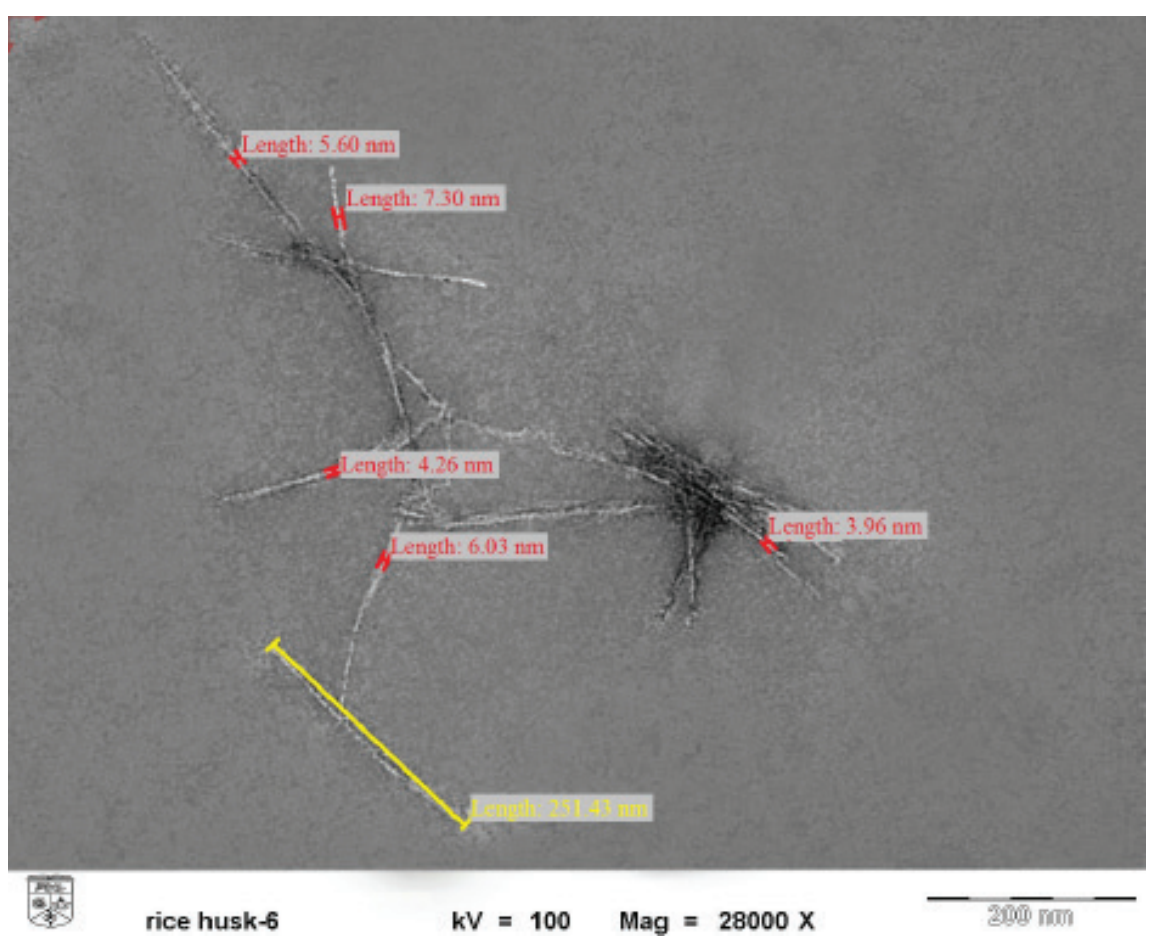

FIGURE 1. Transmission electron micrograph from diluted suspension of cellulose nanocrystals extracted from rice husk fibres 


\section{FOURIER TRANSFORMS INFRARED (FTIR) SPECTROSCOPY}

It can be seen in Figure 2, the presence of $\mathrm{OH}$ stretching vibrations and $\mathrm{C}-\mathrm{H}$ stretching groups in rice husks were indicated by the absorption peaks at 3368 and $2927 \mathrm{~cm}^{-1}$, respectively. The smaller shoulder peak at $1734 \mathrm{~cm}^{-1}$ in raw rice husk was due to the presence of acetyl ester and carbonyl aldehyde groups of hemicellulose and lignin. The peak disappeared upon chemical treatment showing the removal of noncellulosic materials in rice husk. The absorbance peak at $1430 \mathrm{~cm}^{-1}$ assigned to $-\mathrm{CH}_{3}$ asymmetric of lignin was also weakened upon chemical treatments indicating lignin removal. The absorbance peaks at 1376 and $1242 \mathrm{~cm}^{-1}$ can be assigned to $\mathrm{C}-\mathrm{H}$ ester bands and $\mathrm{C}-\mathrm{O}$ stretching vibrations, respectively. The presence of these peaks was due topartial acetylation of hydroxyl groups in both polysaccharides and residual lignin. The decrease in intensity of these peaks showed that lignin content is largely removed after various chemical treatments. The peak at $1059 \mathrm{~cm}^{-1}$ was assigned to $\mathrm{C}-\mathrm{O}-\mathrm{C}$ pyranose ring skeletal vibration. The peak at $898 \mathrm{~cm}^{-1}$ represented the glycosidic $\mathrm{C}-\mathrm{H}$ deformation with ring vibration contribution and
$\mathrm{OH}$ bending in the treated rice husk, indicating the typical structure of cellulose. Comparing both cellulose and CNC's spectra, no significant differences were observed indicated that the molecular structure of cellulose stays the same even after going through acid hydrolysis process (Chen et al. 2011b; Johar et al. 2012; Saha et al. 2010).

In the case of gelatin (Figure 3), peaks at 3289 and $1538 \mathrm{~cm}^{-1}$ were corresponded to $\mathrm{N}-\mathrm{H}$ stretching and N-H bending vibration (amide II), respectively. The peak at $1627 \mathrm{~cm}^{-1}$ reflected the amide $\mathrm{I}(\mathrm{C}=\mathrm{O})$ stretching frequency and peak at $1239 \mathrm{~cm}^{-1}$ was due to the amide III (C-N stretch plus N-H in phase bending). Peak at $1451 \mathrm{~cm}^{-1}$ was corresponded to the bending absorption of the methylene group, while the peak at $1337 \mathrm{~cm}^{-1}$ was assigned to the C-N bond stretching vibrations. The peaks at 1163 and 1081 $\mathrm{cm}^{-1}$ were due to the $\mathrm{C}-\mathrm{O}$ stretching vibrations of gelatin. For gelatin/CNC hydrogel, the increase in intensity at 3289 $\mathrm{cm}^{-1}$ indicated the presence of $\mathrm{CNC}$ in the hydrogel and the peak $1627 \mathrm{~cm}^{-1}$ were due to $\mathrm{C}=\mathrm{N}$ stretching vibration of the imine group of Schiff base which confirmed the formation of cross-link between gelatin chains by glutaraldehyde.

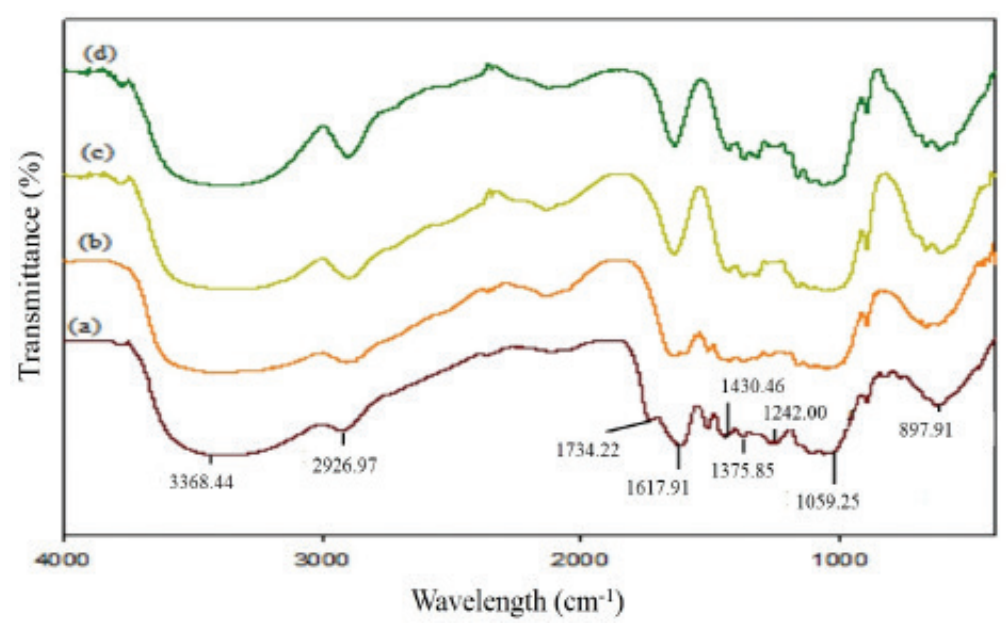

FIGURE 2. FTIR spectra for (a) raw rice husk, (b) alkali-treated rice husk, (c) bleached rice husk and (d) CNC obtained from rice husk after hydrolysis with sulphuric acid

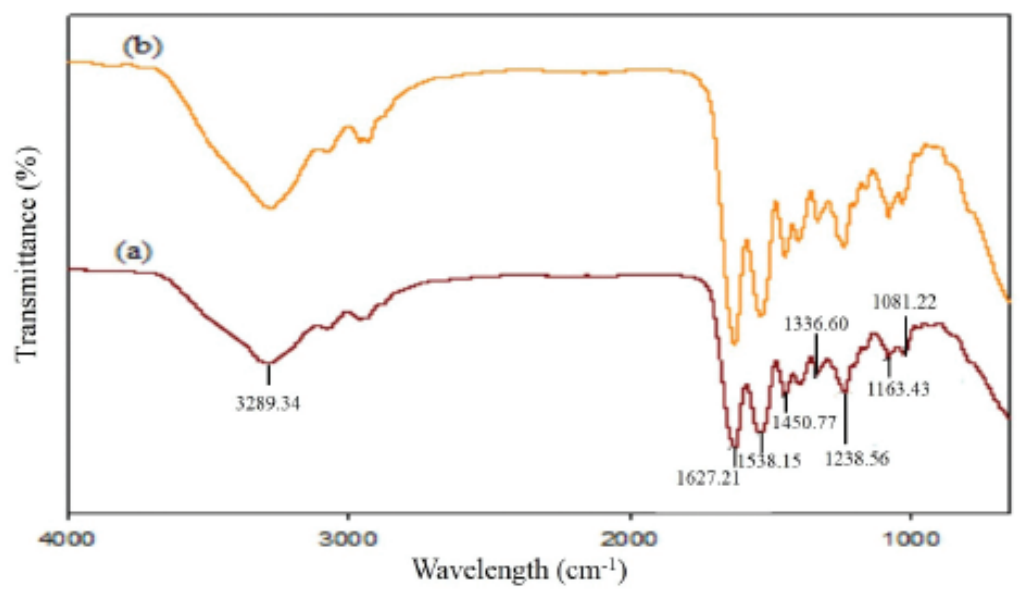

FIGURE 3. FTIR spectra for (a) gelatin and (b) gelatin/CNC hydrogel 


\section{SWELLING TEST}

The swelling tests were conducted to study swelling behaviour of gelatin/CNC hydrogel as a function of time and the results were summarized in Figure 4. Hydrogels were immersed in buffer solutions of $\mathrm{pH}$ range of 3-11 for $48 \mathrm{~h}$.

Gelatin is an amphoteric polymer which can reacts as acid or base because of the presence of carboxyl and amino side chains group. The isoelectric point $(\mathrm{pI})$ of gelatin is 4.9. At this point, the numbers of positive and negative charges are equal, therefore the total charge of the network is zero. The hydrogel network will collapsed due to the electrical attractions between opposite charges. By changing the $\mathrm{pH}$ of medium to increase the degree of ionization, the hydrogels swelled significantly. Below pI, the gelatin network bore a net positively charged yielding a cationic gel. Above pI, the network was negatively charged forming an anionic gel as shown in (1) and (2). The swelling degree was unsymmetric with respect to the isoelectric point, hydrogels with net positive charges had higher swelling ratio compare with hydrogels with net negative charges (Curcio et al. 2010; Jain et al. 2006; Liu et al. 2005). Gelatin/CNC hydrogel achieved highest swelling at $\mathrm{pH} 3$, which was below the $\mathrm{pI}$. At $\mathrm{pH} 5$, which $\mathrm{pH} \approx \mathrm{pI}$, the swelling ratio of hydrogel is minimum. At $\mathrm{pH} 7,9$ and 11 , the swelling ratio increased with increasing counter ions in gelatin hydrogel.

$$
\begin{aligned}
& \text { Gelatin- } \mathrm{NH}_{2} \stackrel{\mathrm{H}^{+}}{\longrightarrow} \text { Gelatin- } \mathrm{NH}_{3}^{+} \text {. } \\
& \text { Gelatin- } \mathrm{COOH} \stackrel{\mathrm{OH}^{+}}{\longrightarrow} \text { Gelatin- } \mathrm{COO}^{-}+\mathrm{H}_{2} \mathrm{O} .(2)
\end{aligned}
$$

\section{THERMOGRAVIMETRIC ANALYSIS (TGA)}

Thermogravimetric analysis (TGA) is used to measure weight loss of material as a function of temperature for a given heating rate. Figure 5 shows the thermal stability of $\mathrm{CNC}$, neat gelatin and gelatin/CNC hydrogel. Usually, thermal chemical degradation of CNC started between 200-300 ${ }^{\circ} \mathrm{C}$ (Moon et al. 2011). Figure 5(a) shows that in the temperature range of $0-100^{\circ} \mathrm{C}$, an initial weight loss was observed which can be linked to water loss due to evaporation. Weight loss appeared at $250-450^{\circ} \mathrm{C}$ was attributed to the degradation of gelatin chain. The higher temperature step $\left(\mathrm{T}>450^{\circ} \mathrm{C}\right)$ was attributed to the decomposition of remaining materials, which were more thermally stable structures due to crosslinking reaction. From the DTG analysis (Figure 5(b)) the maximum degradation temperature of gelatin hydrogel was increased with the incorporation of $\mathrm{CNC}$. The maximum degradation temperature for neat gelatin occurred at $310^{\circ} \mathrm{C}$, whereas for gelatin/CNC hydrogel the degradation occurred at $325^{\circ} \mathrm{C}$. This significant improvement of the thermal resistance may be due to the formation of a more rigid hydrogel structure. The results also indicated good dispersion and well interactions between gelatin and CNC, which imparted stability to the entire system. From the thermogram, it can be seen that the incorporation of $\mathrm{CNC}$ had increased the thermal stability of the hydrogel as the hydrogel degraded at a higher temperature compared with neat gelatin (Li et al. 2013; Mu et al. 2012).

\section{CONCLUSION}

In this study, gelatin/CNC hydrogels were successfully prepared by casting techniques. The FT-IR analysis showed that cross-linking reaction between gelatin monomer had been sucessfully carried out. From the TGA thermogram, it showed that the incorporation of $\mathrm{CNC}$ had effectively increased the thermal stability of the hydrogel. Then, the results of the swelling studies suggested that the hydrogels

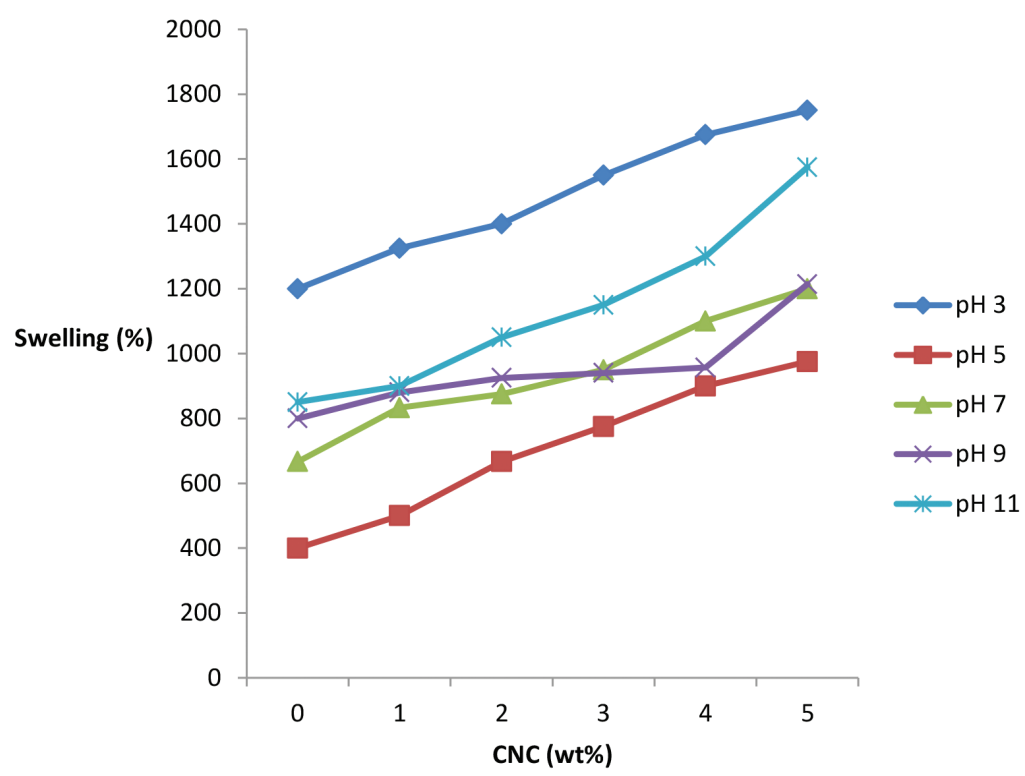

FIGURE 4. Swelling behaviour of gelatin/CNC hydrogels at different $\mathrm{pH}$ 
(a)

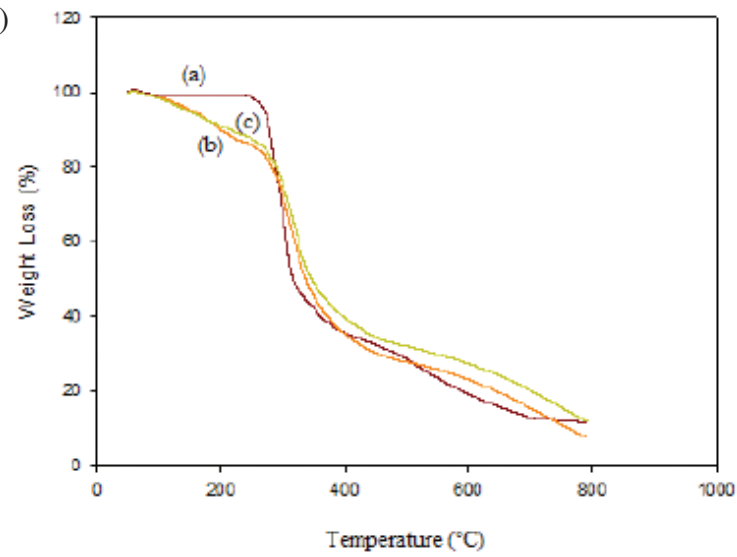

(b)

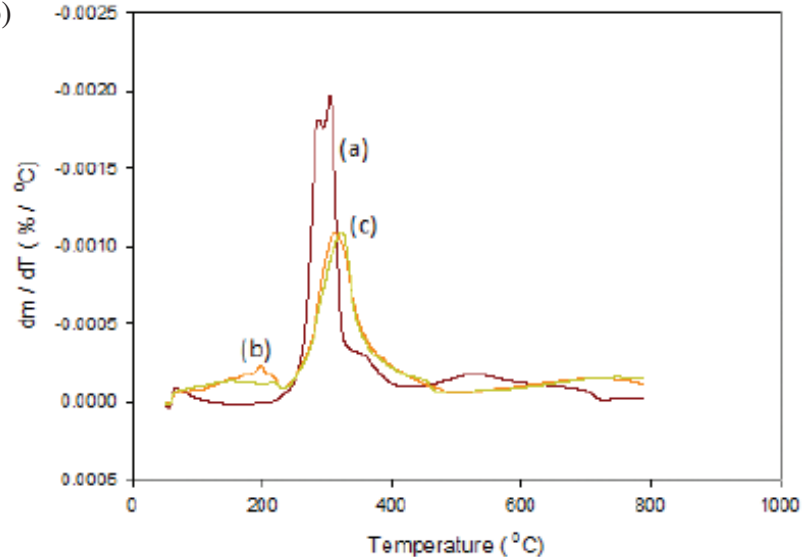

FIGURE 5(a) \& (b). TGA and DTG thermogram for (a) CNC, (b) neat gelatin, (c) gelatin/CNC hydrogel

were $\mathrm{pH}$-sensitive. The gelatin/CNC hydrogels had the highest swelling ratio at $\mathrm{pH}$ less than $\mathrm{pI}$ and lowest swelling ratio at $\mathrm{pH} \approx \mathrm{pI}$.

\section{ACKNOWLEDGEMENTS}

The authors acknowledge the financial support from the Ministry of Science, Technology and Innovation (MOSTI), Malaysia and Universiti Kebangsaan Malaysia (UKM) under Sciencefund grant 03-01-02-SF1106 and Zamalah Scheme of Research University (RU), respectively.

\section{REFERENCES}

Azizi Samir, M.A.S., Alloin, F. \& Dufresne, A. 2005. Review of recent research into cellulosic whiskers, their properties and their application in nanocomposite field. Biomacromolecules 6(2): 612-626

Bell, C.L. \& Peppas, N.A. 1996. Water, solute and protein diffusion in physiologically responsive hydrogels of poly (methacrylic acid-g-ethylene glycol). Biomaterials 17(12): 1203-1218.

Bigi, A., Cojazzi, G., Panzavolta, S., Roveri, N. \& Rubini, K. 2002. Stabilization of gelatin films by crosslinking with genipin. Biomaterials 23(24): 4827-4832.

Carvalho, R.A. \& Grosso, C.R.F. 2004. Characterization of gelatin based films modified with transglutaminase, glyoxal and formaldehyde. Food Hydrocolloids 18(5): 717-726.

Chen, J.P., Leu, Y.L., Fang, C.L., Chen, C.H. \& Fang, J.Y. 2011a. Thermosensitive hydrogels composed of hyaluronic acid and gelatin as carriers for the intravesical administration of cisplatin. J. Pharm. Sci. 100(2): 655-666.

Chen, X., Yu, J., Zhang, Z. \& Lu, C. 2011b. Study on structure and thermal stability properties of cellulose fibers from rice straw. Carbohydrate Polymers 85(1): 245-250.

Curcio, M., Gianfranco Spizzirri, U., Iemma, F., Puoci, F., Cirillo, G., Parisi, O.I. \& Picci, N. 2010. Grafted thermoresponsive gelatin microspheres as delivery systems in triggered drug release. European Journal of Pharmaceutics and Biopharmaceutics 76(1): 48-55.

Draye, J.P., Delaey, B., Van de Voorde, A., Van Den Bulcke, A., De Reu, B. \& Schacht, E. 1998. In vitro and in vivo biocompatibility of dextran dialdehyde cross-linked gelatin hydrogel films. Biomaterials 19(18): 1677-1687.
Eichhorn, S.J. 2011. Cellulose nanowhiskers: Promising materials for advanced applications. Soft Matter. 7(2): 303-315.

Farris, S., Song, J. \& Huang, Q. 2009. Alternative reaction mechanism for the cross-linking of gelatin with glutaraldehyde. Journal of Agricultural and Food Chemistry 58(2): 998-1003.

Frisk, M.L., Tepp, W.H., Lin, G., Johnson, E.A. \& Beebe, D.J. 2007. Substrate-modified hydrogels for autonomous sensing of botulinum neurotoxin type a. Chemistry of Materials 19(24): 5842-5844

Frutos, G., Prior-Cabanillas, A., París, R. \& Quijada-Garrido, I. 2010. A novel controlled drug delivery system based on pH-responsive hydrogels included in soft gelatin capsules. Acta Biomaterialia 6(12): 4650-4656.

Gojgini, S., Tokatlian, T. \& Segura, T. 2011. Utilizing cell-matrix interactions to modulate gene transfer to stem cells inside hyaluronic acid hydrogels. Molecular Pharmaceutics 8(5): 1582-1591.

Hou, Y., Schoener, C.A., Regan, K.R., Munoz-Pinto, D., Hahn, M.S. \& Grunlan, M.A. 2010. Photo-cross-linked pdmsstar-peg hydrogels: Synthesis, characterization, and potential application for tissue engineering scaffolds. Biomacromolecules 11(3): 648-656.

Jagadeeshbabu, P.E., Suresh Kumar, R. \& Maheswari, B. 2011. Synthesis and characterization of temperature sensitive P-NIPAM macro/micro hydrogels. Colloids and Surfaces A: Physicochemical and Engineering Aspects 384(1-3): 466-472.

Jain, S.K., Agrawal, G.P. \& Jain, N.K. 2006. A novel calcium silicate based microspheres of repaglinide: In vivo investigations. Journal of Controlled Release 113(2): 111116.

Johar, N.,Ahmad, I. \& Dufresne,A. 2012. Extraction, preparation and characterization of cellulose fibres and nanocrystals from rice husk. Industrial Crops and Products 37(1): 93-99.

Karlsson, J.O. \& Gatenholm, P. 1999. Cellulose fibre-supported pH-sensitive hydrogels. Polymer 40(2): 379-387.

Khor, E. 1997. Methods for the treatment of collagenous tissues for bioprostheses. Biomaterials 18(2): 95-105.

Klemm, D., Kramer, F., Moritz, S., Lindström, T., Ankerfors, M., Gray, D. \& Dorris, A. 2011. Nanocelluloses: A new family of nature-based materials. Angewandte Chemie International Edition 50(24): 5438-5466.

Kuijpers, A.J., Engbers, G.H.M., Feijen, J., De Smedt, S.C., Meyvis, T.K.L., Demeester, J., Krijgsveld, J., Zaat, S.A.J. \& 
Dankert, J. 1999. Characterization of the network structure of carbodiimide cross-linked gelatin gels. Macromolecules 32(10): 3325-3333.

Lee, K.Y.\& Mooney, D.J. 2001. Hydrogels for tissue engineering. Chemical Reviews 101(7): 1869-1880.

Lee, K.Y., Shim, J. \& Lee, H.G. 2004. Mechanical properties of gellan and gelatin composite films. Carbohydrate Polymers 56(2): 251-254.

Li, H., Yuan, Z., Lam, K.Y., Lee, H.P., Chen, J., Hanes, J. \& Fu, J. 2004. Model development and numerical simulation of electric-stimulus-responsive hydrogels subject to an externally applied electric field. Biosensors and Bioelectronics 19(9): 1097-1107.

Li, W., Guo, R., Lan, Y., Zhang, Y., Xue, W. \& Zhang, Y. 2013. Preparation and properties of cellulose nanocrystals reinforced collagen composite films. Journal of Biomedical Materials Research Part 102(4): 1131-1139.

Lindblad, M.S., Sjöberg, J., Albertsson, A.C. \& Hartman, J. 2007. Hydrogels from polysaccharides for biomedical applications. ACS Symposium Series 954: 153-167.

Liu, J., Lin, S., Li, L. \& Liu, E. 2005. Release of theophylline from polymer blend hydrogels. International Journal of Pharmaceutics 298(1): 117-125.

Liu, T.Y., Hu, S.H., Liu, K.H., Liu, D.M. \& Chen, S.Y. 2006. Preparation and characterization of smart magnetic hydrogels and its use for drug release. Journal of Magnetism and Magnetic Materials 304(1): e397-e399.

Moon, R.J., Martini, A., Nairn, J., Simonsen, J. \& Youngblood, J. 2011. Cellulose nanomaterials review: Structure, properties and nanocomposites. Chemical Society Reviews 40(7): 3941-3994.

Moriyama, K., Minamihata, K., Wakabayashi, R., Goto, M. \& Kamiya, N. 2013. Enzymatic preparation of streptavidinimmobilized hydrogel using a phenolated linear poly(ethylene glycol). Biochemical Engineering Journal 76(0): 37-42.

Mu, C., Guo, J., Li, X., Lin, W. \& Li, D. 2012. Preparation and properties of dialdehyde carboxymethyl cellulose crosslinked gelatin edible films. Food Hydrocolloids 27(1): 22-29.

Murdan, S. 2003. Electro-responsive drug delivery from hydrogels. Journal of Controlled Release 92(1-2): 1-17.

Paulino, A.T., Pereira, A.G.B., Fajardo, A.R., Erickson, K., Kipper,M.J., Muniz,E.C., Belfiore, L.A.\& Tambourgi,E.B. 2012. Natural polymer-based magnetic hydrogels: Potential vectors for remote-controlled drug release. Carbohydrate Polymers 90(3): 1216-1225.

Peng, B.L., Dhar, N., Liu, H.L. \& Tam, K.C. 2011. Chemistry and applications of nanocrystalline cellulose and its derivatives: A nanotechnology perspective. The Canadian Journal of Chemical Engineering 89(5): 1191-1206.

Pezron, I., Djabourov, M. \& Leblond, J. 1991. Conformation of gelatin chains in aqueous solutions: 1. A light and small-angle neutron scattering study. Polymer 32(17): 3201-3210.

Prestwich, G.D., Marecak, D.M., Marecek, J.F., Vercruysse, K.P. \& Ziebell, M.R. 1998. Controlled chemical modification of hyaluronic acid: Synthesis, applications, and biodegradation of hydrazide derivatives. J. Control Release 53(1-3): 93-103.

Qiu, Y. \& Park, K. 2012. Environment-sensitive hydrogels for drug delivery. Advanced Drug Delivery Reviews 53(3): 321-329.
Rodríguez, R.A., Alvarez-Lorenzo, C. \& Concheiro, A. 2003. Cationic cellulose hydrogels: Kinetics of the cross-linking process and characterization as $\mathrm{pH}$-/ion-sensitive drug delivery systems. Journal of Controlled Release 86(2-3): 253-265.

Ross-Murphy, S.B. 1992. Structure and rheology of gelatin gels: Recent progress. Polymer 33(12): 2622-2627.

Saha, P., Manna, S., Chowdhury, S.R., Sen, R., Roy, D. \& Adhikari, B. 2010. Enhancement of tensile strength of lignocellulosic jute fibers by alkali-steam treatment. Bioresource Technology 101(9): 3182-3187.

Shang, J., Shao, Z. \& Chen, X. 2008. Chitosan-based electroactive hydrogel. Polymer 49(25): 5520-5525.

Spizzirri, U.G., Iemma, F., Puoci, F., Cirillo, G., Curcio, M., Parisi, O.I. \& Picci, N. 2009. Synthesis of antioxidant polymers by grafting of gallic acid and catechin on gelatin. Biomacromolecules 10(7): 1923-1930.

Wan, Y., Wang, Y., Cheng, G. \& Yao, K. 2000. Preparation and characterization of gelatin gel with a gradient structure. Polymer International 49(12): 1600-1603.

Ward, A.G. \& Courts, A. 1977. The Science and Technology of Gelatin. New York: Academic Press.

Wu, D.Q., Qiu, F., Wang, T., Jiang, X.J., Zhang, X.Z. \& Zhuo, R.X. 2008. Toward the development of partially biodegradable and injectable thermoresponsive hydrogels for potential biomedical applications. ACS Applied Materials \& Interfaces 1(2): 319-327.

Zhang, H., Patel, A., Gaharwar, A.K., Mihaila, S.M., Iviglia, G., Mukundan, S., Bae, H., Yang, H. \& Khademhosseini, A. 2013. Hyperbranched polyester hydrogels with controlled drug release and cell adhesion properties. Biomacromolecules 14(5): 1299-1310.

Zhang, J.T., Bhat, R. \& Jandt, K.D. 2009. Temperature-sensitive PVA/PNIPAAm semi-IPN hydrogels with enhanced responsive properties. Acta Biomaterialia 5(1): 488-497.

Zhang, X., Huang, J., Chang, P.R., Li, J., Chen, Y., Wang, D., Yu, J. \& Chen, J. 2010. Structure and properties of polysaccharide nanocrystal-doped supramolecular hydrogels based on Cyclodextrin inclusion. Polymer 51(19): 4398-4407.

Zhu, D., Jin, L., Wang, Y. \& Ren, H. 2012. Swelling behavior of gelatin-based hydrogel cross-linked with microbial transglutaminase. Journal of Aqeic 63: 11-20.

Ooi Shok Yin \& Ishak Ahmad*

Faculty of Science and Technology

Universiti Kebangsaan Malaysia

43600 Bangi, Selangor Darul Ehsan

Malaysia

Mohd Cairul Iqbal Mohd Amin

Faculty of Pharmacy, Universiti Kebangsaan Malaysia

Jalan Raja Muda Abdul Aziz

50300 Kuala Lumpur

Malaysia

*Corresponding author; email: gading@ukm.edu.my

Received: 15 January 2014

Accepted: 15 November 2014 